\title{
Effect of Drying Techniques on Nutrition Content and Gross Energy of Nuabosi Cassava (Manihot esculenta) Flour
}

\author{
Melania Priska $^{1 *}$, Natalia Peni ${ }^{2}$, Ludovicus Carvallo ${ }^{2}$, Veronika P. S. M. Wae ${ }^{1}$ \\ ${ }^{1}$ Biology Education Department; ${ }^{2}$ Mathematics Education Department, \\ Faculty of Teacher Training and Education, Universitas Flores, Indonesia \\ *Email: pika87cutes@gmail.com
}

Submitted: 26 April 2020. Revised: 14 June 2020. Accepted: 1 July 2020

\begin{abstract}
This reseach aimed to determine the proper cassava drying technique to produce suitable flour properties for food product applications. The method used was proximate analysis and calculation of Gross Energy (GE) value. Furthermore, the results of the study were analyzed using the Two Way ANOVA statistical test followed by the real difference test using the Tukey analysis. Results of the analysis showed that there was no significant difference between the two drying techniques $(\alpha>0.05)$. To get good quality flour in the application of food products made from Nuabosi cassava flour is to use oven drying and sun drying techniques. The novelty of this study is that there has been no previous research on the quality of Nuabosi cassava flour using oven drying and sun drying techniques. The benefit of this research is to support the government in the food diversification program on foods made from Nuabosi cassava flour, where Nuabosi cassava is one of the leading types of food in Ende district.
\end{abstract}

Key words: Cassava (Manihot esculenta Crantz); Drying Technique; Nutrient Content; Gross Energy (GE)

How to Cite: Priska, M., Peni, N., Carvallo, L., \& Wae, V. P. (2020). Effect of Drying Techniques on Nutrition Content and Gross Energy of Nuabosi Cassava (Manihot esculenta) Flour. Biosaintifika: Journal of Biology \& Biology Education, 12 (2), $220-225$

DOI: http://dx.doi.org/10.15294/biosaintifika.v12i2.24184

\section{INTRODUCTION}

Research in the food industry is currently being developed using agricultural resources which are abundant in availability, so that they can make important contributions to the development of science and technology. One of the most widely produced agricultural products is cassava (Ministry of Agriculture, 2016). Cassava (Manihot esculenta Crantz.) is a local food as the third source of carbohydrate in Indonesia after rice and corn. It is also cheap and easy to reach by the community.

Based on 2015 Central Statistics Agency data, the amount of cassava production in Indonesia in 2014 was 23.44 million tons (Fathoni et al., 2016). One of the regions that produces the highest yield of cassava is Ende district in East Nusa Tenggara. Data from the NTT Central Statistics Agency in 2014 stated that cassava production in 2013 was 811,166 tons.

The amount of cassava production in this area is quite large but its utilization has not been maximized. People only used it as a local food source of carbohydrates with a short shelf life due to the lack of local knowledge about cassava processing. However, along with the development of science and technology, cassava processing methods must be adjusted to the desires and interests of consumers (Mujiati et al., 2018). Therefore, efforts should be made to improve the quality of processing method of cassava into semiprocessed products so that it can be stored for a long time. One form of semi-processed products derived from cassava is cassava flour. Cassava flour can be used as a raw material in the manufacture of various processed foods, such as pastries, cakes, and other product mixes made from wheat or rice flour (Haloho, 2014).

There are several types of local varieties of cassava found in mainland Flores-NTT, one of which is Nuabosi cassava. Nuabosi cassava consists of 2 types, namely Tana Ae and Terigu. According to the community, Nuabosi cassava is a widely consumed variety because it is tasty and juicy. The flavor of cassava is influenced by the physical and chemical properties of the soil, harvesting time and cultivation techniques (Subekti et al., 2018). The time of harvesting Nuabosi cassava type Tana Ae and Terigu is about 6 months 1 year after planting.

Based on the explanation above, cassava has great potential to support a flour-based food diversification program. The effort to process cassava into flour is one of the methods of preserving cassava with abundant production and relatively short storage time, which only lasts 2-3 days in a fresh condition (Nugraheni et al., 2015). Cassava in the form of flour has a relatively long storage period ranging from 3-6 months (Paramita et al., 2015). In addition, other advantages that can be obtained are the application of flour will be wider because it can be processed into a variety of food products that do not require high technology, it is also practical in transportation and stor- 
age, and can be applied by the community to increase the economic value of cassava as well as the income of cassava farmers (Ihromi et al., 2018).

Processing of cassava into flour is passed through various techniques, one of which is drying. Drying is one way to preserve perishable food. The goal of this technique is to reduce the water content of a food to $<12 \%$, so that its shelf life will be longer and it will not be overgrown by microbes (Yulifianti et al., 2012). Water content in cassava generally ranges around $60-65 \%$. An effective drying technique used to minimize damage to cassava is natural drying using the heat from the sun and kinetic drying using an oven (Saepudin et al., 2017). The research aimed to determine the right drying technique to produce flour that is suitable for the application of flour-based food products. The benefit of this research is to support the government in the food diversification program on foods made from Nuabosi cassava flour, where Nuabosi cassava is one of the leading types of food in Ende district.

\section{METHODS}

The research was carried out in June - August 2019. All tests in the study were conducted at the Environmental Agency Laboratory, Ende regency and at the Nutrition and Animal Feed Laboratory of Kupang State Polytechnic of Agriculture. The testing of nutritional content and gross energy of Nuabosi cassava flour consisted of several stages. The initial stage was sample preparation, followed by the manufacture of Nuabosi cassava flour, proximate analysis (carbohydrate, fat, protein, crude fiber, water and ash) and gross energy analysis. Furthermore, the data obtained were analyzed with the Two Way ANOVA statistical test. The significant difference results between treatments was continued with the Tukey real difference test. Data was processed using SPSS version 21.0.

Tools and materials used in this study were rotary vacum evaporators, soklet flasks, desicators, disc mills, sets of destructor, a set of Buchner filters, a set of titration apparatus, oven, furnace, bomb calorimeter, Nuabosi cassava tubers, whatman filter paper, $1 \mathrm{~L}$ distilled water, $1 \mathrm{~L}$ double distilled water, $150 \mathrm{ml}$ hexane, $0.25 \mathrm{~g}$ selenium, $3 \mathrm{~mL}$ concentrated $\mathrm{H}_{2} \mathrm{SO}_{4}, 25 \mathrm{~mL} \mathrm{H}_{2} \mathrm{SO}_{4} 1.25 \%, 20 \mathrm{~mL} 40 \% \mathrm{NaOH}, 20$ $\mathrm{mL} 1.25 \% \mathrm{NaOH}, 10 \mathrm{~mL} 2 \% \mathrm{H}_{3} \mathrm{BO}_{3}, 25 \mathrm{~mL}$ alcohol, $0.1 \mathrm{~N} \mathrm{HCl}, 2$ drops of Bromine cresol greenmethyl red indicator, $\mathrm{Na}_{2} \mathrm{CO}_{3}$, platinum wire, and methyl orange indicator.

\section{Sample Preparation}

Fresh Nuabosi cassava samples were collected, cleaned from dirt and soil, then washed with running water. After that, the samples were peeled and the rotten parts are removed using a knife.

\section{Manufacturing of Nuabosi Cassava Flour}

In this study, an analysis of the nutrient content of Nuabosi cassava flour was based on the drying technique. The treatment consisted of 2 techniques, namely technique 1 (shredded, fresh, dried by sun drying), technique 2 (shredded, fresh, dried by oven drying).

Drying shredded Nuabosi cassava using sun drying technique usually does not require a long time. The drying process in sunny weather was carried out for \pm 3-4 days until the Nuabosi cassava was dried, with a moisture content of about $20 \%$, while for the drying technique using an oven, the temperature used was between $70{ }^{\circ} \mathrm{C}-80{ }^{\circ} \mathrm{C}$ for $\pm 6-16$ hours (Erni et al., 2018).

Dried Nuabosi cassava was crushed with a disc mill and sifted using an 80 mesh sieve. After these steps were passed, cassava flour produced was used for further analysis. Analysis conducted on Nuabosi cassava flour was a proximate (analysis of water, ash, fat, protein content, crude fiber, and carbohydrate content) and gross energy analysis. The method used in the analysis of proximate and gross energy was according to the Association of Official Analytical Chemist (AOAC) Method (Ariani et al., 2017).

\section{Proximate Analysis}

Water Content Analysis. A total of 5 grams of sample was weighed in a cup, put in an oven at $105^{\circ} \mathrm{C}$ for 8 hours, then weighed. Moisture content was calculated by the following formula:

Water content $(\%)=\frac{\text { Sample weight }(\text { Fresh- Dry) }}{\text { Fresh sample weight }} \times 100 \%$

Ash Content Analysis. A total of 5 grams of sample was put into a porcelain cup, burned until it was not smoky, then blended in a furnace at $600{ }^{\circ} \mathrm{C}$ for 6 hours. The sample was then cooled in a desiccator for \pm 1 hour and was weighed. Ash content was calculated by the formula as follows:

Ash content $(\%)=\frac{\text { Ash weight }}{\text { Sample weight }} \times 100 \%$

Fat Analysis. A total of 5 grams of sample was spread on a cotton cloth with filtered paper and rolled to form lead, then put into a soklet flask. Then, it was extracted for 6 hours with $150 \mathrm{~mL}$ of hexane fat solvent. The extracted fat was dried in an oven at $105^{\circ} \mathrm{C}$ for 1 hour. Fat content can be calculated by the formula as follows:

Fat content $(\%)=\frac{\text { Extracte d fat weight }}{\text { Sample weight }} \times 100 \%$ 
Analysis of Protein Levels. A total of 0.25 grams of sample was put into a $100 \mathrm{~mL}$ kjeldahl flask and then added with 0.25 gram selenium and $3 \mathrm{~mL}$ of concentrated $\mathrm{H}_{2} \mathrm{SO}_{4}$. Then the sample is destructed (heating in a boiling state) for 1 hour until the solution was clear. After chilling, $50 \mathrm{~mL}$ of distilled water and $20 \mathrm{~mL}$ of $40 \% \mathrm{NaOH}$ was added. The process was continued by distillation, the product was collected in an erlenmeyer flask containing a mixture of 10 $\mathrm{mL}$ of $2 \% \mathrm{H}_{3} \mathrm{BO}_{3}$ and 2 drops of the pink indicator of Bromine cresol green-methyl red. After the distillate volume became $10 \mathrm{~mL}$ and turned bluish green, the distillation was stopped and followed by titration with $0.1 \mathrm{~N} \mathrm{HCl}$ to pink. The same treatment was also carried out on blanks. Total nitrogen content was calculated by the formula as follows:

Nitrogen content $(\%)=\frac{(\mathrm{S}-\mathrm{B}) \times \mathrm{NHCl} \times 14}{\mathrm{~W} \times 1000} \times 100 \%$

Note: S: Sample titrant volume $(\mathrm{mL})$, B: blank titrant volume $(\mathrm{mL}), \mathrm{W}$ : dry sample weight $(\mathrm{mg})$. Protein content was obtained by multiplying the nitrogen content by multiplication factors for various foods ranging from 5.18-6.38 (AOAC, 1980).

Crude Fiber Analysis. A total of 1 gram of sample was dissolved with $100 \mathrm{~mL}$ of $1.25 \% \mathrm{H}_{2} \mathrm{SO}_{4}$, heated to boiling then followed by destruction for 30 minutes. After that, the sample was filtered with filter paper with the help of a buchner funnel. The filter residue was rinsed with $20-30 \mathrm{~mL}$ boiling water and with $25 \mathrm{~mL}$ water for 3 times. The residue was destructed with $1.25 \% \mathrm{NaOH}$ for 30 minutes. Then, it was filtered again as above and rinsed consecutively with $25 \mathrm{~mL}$ of $\mathrm{H}_{2} \mathrm{SO}_{4} 1.25 \%$ (boiling), $25 \mathrm{~mL}$ of water three times and $25 \mathrm{~mL}$ of alcohol. The residue and filter paper were transferred to a porcelain cup, weighed, then put in a $600{ }^{\circ} \mathrm{C}$ furnace for 30 minutes, cooled and re-weighed. Crude fiber was calculated by the following formula:

Crude fiber content $(\%)=\frac{\text { Crude fiber weight }}{\text { Sample weight }} \times 100 \%$

Carbohydrate Analysis. Total carbohydrate was determined by the carbohydrate by difference method as follows:

\section{$100 \%$ - (water content + ash + protein + fat $)$}

Gross Energy Analysis (GE). One gram of flour sample was put into a small cup, then passed through a $10 \mathrm{~cm}$ long platinum wire and put again into a bomb calorimeter. Before being filled with 25 atmospheric oxygen gas, the bomb calorimeter was filled with a little distilled water. The calorimeter bomb was inserted into a jacket that has been filled with water and then closed. The temperature was stabilized by turning the knob. After the stable temperature was recorded as the initial temperature (a), samples were burned by pressing a button or knob and left for 5 minutes. Then the temperature was stabilized again by pressing the temperature button. A stable temperature was recorded as the final temperature. The cup and bomb calorimeter tube were washed with a mixture of distilled water with the methyl orange indicator. The washing was titrated with sodium carbonate $\left(\mathrm{Na}_{2} \mathrm{CO}_{3}\right)$. Burnt platinum wire was measured as $k$ calories. The amount of gross energy (GE) of a food ingredient was calculated by formula as follow:

$\mathrm{GE}($ Calory $/ g)=\frac{(b-a) \mathrm{x} w-\mathrm{k}-\mathrm{ti}}{\text { Sample weight }}$

Note:

$\mathrm{b}=$ final temperature ${ }^{\circ} \mathrm{C}$

$\mathrm{a}=$ initial temperature ${ }^{\circ} \mathrm{C}$

$\mathrm{k}=$ burnt platinum wire (calory)

$\mathrm{ti}=$ volume $\mathrm{Na}_{2} \mathrm{CO}_{3}$ used to reach endpoint

$\mathrm{w}=2589$ (water equivalent)

\section{RESULTS AND DISCUSSION}

\section{Proximate Analysis of Cassava Flour Made From Nuabosi Tana Ae (TA) and Terigu Varieties}

Every food crop has a chemical content that has nutritional value (Sakya, 2016). However, the quality of natural chemicals will change due to the drying process (Rohyani et al., 2015). Proper drying technique will produce flour with a good quality, long shelf life and stable nutritional ingredient (Wahyuni et al., 2014). The results of the analysis of real difference test for Nuabosi cassava flour are presented in Figure 1.

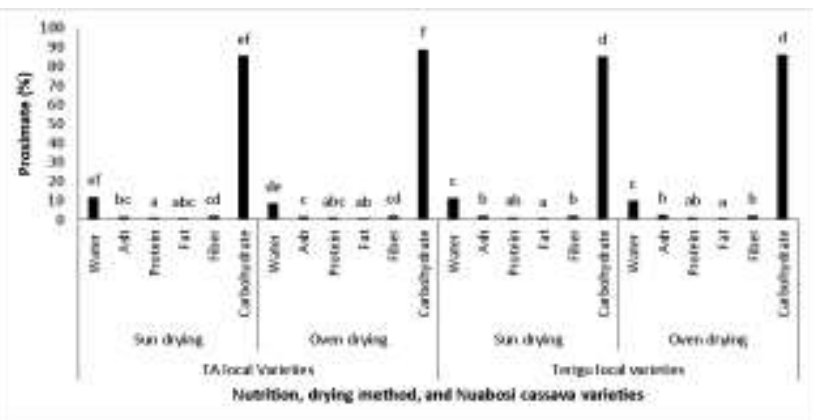

Figure 1. Proximate Results from the Analysis of Real Differences Test using Tukey

The nutritional content of Nuabosi cassava is influenced by the variety. Different varieties produce different nutritional values. This is shown in Figure 1 that both varieties have different nutritional values even though the drying technique used was similar. Figure 1 shows that the nutrients in the Terigu variety were not significantly different between the two drying techniques (value $\alpha>0.05$ ). No significant difference is indicated by the same notation for nutrients in 
the Terigu variety for both drying techniques. The water, ash, protein, fat, and carbohydrate content of the wheat flour varieties did not differ significantly between the two drying techniques. The different notation is shown in the nutritional content found in the TA variety. These results indicate that the nutrient content in the TA varieties was significantly different in the two drying techniques (value $\alpha<0.05$ ). Cassava flour TA varieties using sun drying techniques have high water content (ef notation) and low ash content (bc notation). The fat content (abc notation) and fiber (cd notation) in the two drying techniques are not significantly different because both have the same notation. Moreover, carbohydrate content in the technique of drying using the sun and oven drying is significantly different. This is shown by the higher carbohydrate content in oven drying (f notation) compared to drying using the sun (ef notation) (Figure 1) (Tambunan et al., 2017).

Ash content shows the total inorganic mineral content found in Nuabosi cassava flour. The inorganic mineral content in the ash content analysis is the material left on cassava flour at the time of combustion using temperatures between $500^{\circ} \mathrm{C}$ $800^{\circ} \mathrm{C}$. Flour of both varieties affect the composition and percentage of ash in cassava flour (Sundari et al., 2015).

In the sun drying technique there is still water content in Nuabosi cassava flour which has the potential as an indicator of biochemical reactions, thus damaging the nutritional content of flour. The change in biochemical reactions that occurs in flour causes the resistance of nutrient content to microbial contamination decreases. This causes cassava flour can not be stored for a long time because it will experience damage, such as the growth of fungus or mold on cassava flour (Salimna et al., 2014).

Protein content in Nuabosi cassava flour is closely related to the amount of water content in the flour. The lower the water content, the higher the protein content in flour. Oven drying technique is more effective than the sun drying, because the heat from the oven can reduce the percentage of water content which affects an increase in protein content (Riansyah et al., 2013).

The crude fat content of Nuabosi cassava flour of Tana Ae (TA) varieties using the oven drying technique produces the lowest crude fat content. This is because the heat energy in the oven does not undergo refraction since it is in a closed room. The heat causes lipase enzymes contained in flour to accelerate the process of fat hydrolysis, so that the crude fat content in flour Tana Ae varieties are lower. In the Terigu variety, the drying treatment is the same as the Tana Ae variety, but in the Terigu variety, the fat content produced does not show any significant difference between the two drying techniques. This is because the length of time to harvest Terigu varieties is longer which is 1.5 years, whereas for Tana Ae varieties the harvest time is 7-8 months (Sarastuti \& Yuwono, 2015; Aliya et al., 2016).

Carbohydrate content in Tana Ae (TA) variety flour is influenced by water content and fat content. If the proportion of water and fat is small, the carbohydrate will be even greater. A decrease in water and fat content in a food will cause the concentration of other compounds, such as carbohydrates and proteins, to be higher. Carbohydrates in food ingredients play an important role in determining the flavor, color, and texture (Sarifudin et al., 2015).

Research on the nutritional and toxicological composition analysis of some MU51 cassava products by Rajapaksha et al. (2017) showed that cassava processed product in the form of flour that was made by means of drying had a significant difference in nutrient content compared to the fresh cassava. The results showed that the drying technique affected the nutritional content of cassava flour.

\section{Gross Energy (GE) of cassava flour made from Nuabosi Tana Ae (TA) and Terigu Varieties}

Gross energy (GE) is the potential energy contained in food that can not be used directly by humans. GE contained in food will be utilized by humans if it is converted into available energy through the process of digestion, absorption, and metabolism in the body. The available energy is used by humans to fulfill basic life needs, such as growth, development, and reproduction. The amount of energy in food is an aspect that determines the amount of food consumed by humans to meet energy needs in the body (Fitasari \& Santoso, 2015).

The amount of gross energy to support the metabolic process depends on the ability of humans to digest food. In the process of metabolism, there is a breakdown of complex chemical compounds in food ingredients into smaller molecules that can be absorbed and used by humans (Juliati et al., 2016). The results of the analysis of real difference test on the GE of Nuabosi cassava flour are presented in Figure 2.

Figure 2 shows that the GE between the two drying techniques was not significantly different ( $\alpha$ value $>0.05$ ). No significant difference was indicated by the same notation (a) on the the varieties of Terigu and Tana Ae for both drying techniques. The results show that both drying techniques can be applied to get good quality flour. Gross energy of local Terigu from oven and sun drying is $3716.005 \mathrm{Cal} / \mathrm{g}$ and $3810.902 \mathrm{Cal} / \mathrm{g}$, respectively, while the gross energy of the TA flour is $3655.925 \mathrm{Cal} / \mathrm{g}$ and $3610.903 \mathrm{Cal} / \mathrm{g}$ respectively. 


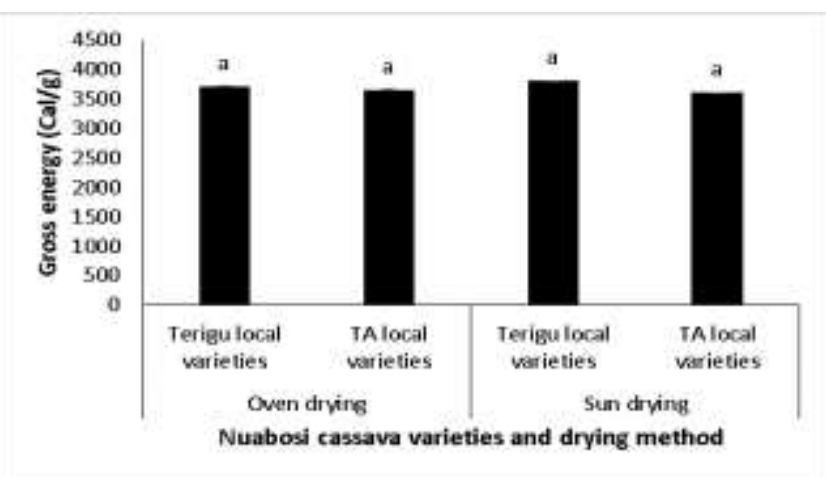

Figure 2. Results of the Analysis of Real Differences on Gross Energy using Tukey test

The high value of gross energy is influenced by the nutrient contained in food ingredients, such as carbohydrate, protein, fat, and fiber. Thus, the higher the nutritional content of food ingredients, the higher the value of their gross energy (Pangestu et al., 2018). Both drying techniques are effective to produce highquality flour. The novelty of this study is that there has been no previous research on the quality of Nuabosi cassava flour using oven drying and sun drying techniques. The benefit of this research is to support the government in the food diversification program on foods made from Nuabosi cassava flour, where Nuabosi cassava is one of the leading types of food in Ende district.

\section{CONCLUSION}

Based on the results of research and discussion, it can be concluded that an effective drying technique to get good flour quality in the application of food products made from Nuabosi cassava flour is to use oven and sun drying techniques. Quality flour can support the government in the food diversification program on foodstuffs made from Nuabosi cassava flour.

\section{REFERENCES}

Aliya, L. S., Rahmi, Y., \& Soeharto, S. (2016). Mi "Mocafle" Increased Nutritional Content of Dried Noodles Based on Functional Local Food. Indonesian Journal of Human Nutrition 3 (1): 32 - 41.

Ariani, L. N., Estiasih, T., \& Martati, E. (2017). Physicochemical Characteristic of Cassava (Manihot utilisima) with Different Cyanide Level. Journal of Agriculture Technology 18 (2): 119 128.

Erni, N., Kadirman, \& Fadilah, R. (2018). Effect of Temperature and Drying Time on the Chemical and Organoleptic Properties of Taro Bulbs (Colocasia esculenta) Flour. Journal of Agricultural Technology Education 4 (1): 95 - 105.
Fathoni, A., N. S. Hartati, \& N. K. I. Mayasti. (2016). Minimization of Reduction of Beta-Carotene and Protein Levels in the Production Process of Cassava Flour. Journal of Food 25 (2): 113 - 124. DOI: 10.33964 / jp.v25i2,327.

Fitasari, E. \& Santoso, E. P. (2015). Use of a Combination of Gross Energy and Protein on Feed Consumption and Development of Hong Kong Caterpillar Body Weights. Buana Science 15 (2): 127 136.

Haloho, J. D. (2014). Processing of Cassava in an Effort to Accelerate Food Diversification in West Kalimantan. Proceedings of the Seminar on the Results of Research on Various Plants of Beans and Bulbs pp 775 - 786.

Ihromi, S., Marianah, \& Susandi, Y. A. (2018). Substitution of Wheat Flour with Mocaf Flour in Making Cookies. Journal of Agrotech Ummat 5 $\begin{array}{lllll}\text { (1): } & 73 & - & 77 . & \text { DOI: }\end{array}$ https://doi.org/10.31764/agrotek.v5i1.271.

Juliati, K., Sudrajat, D., \& Kardaya, D. (2016). The Effect of Substitution of Coconut Dregs in Commercial Feed on the Energy of Metabolism of Kampung Chickens. Journal of Animal Husbandry 2 (1): 159 - 164.

Ministry of Agriculture. (2016). Outlook: Agricultural Commodities Sub Sector Food Crop. Jakarta: Center for Agriculture Data and Information Systems Ministry of Agriculture.

Mujiati, Ibrahim, M. N., \& Isamu, K. T. (2018). Comparison Test of Pokea Meat (Batissa violacea celebensis Martens 1897) and Tapioca Flour which are Different to the Characteristics of Pokea Crackers. Journal of Fish Protech 1 (1): 38-47. ISSN: 2621-1475.

Nugraheni, M., Handayani, T. H. W., \& Utama, A. (2015). Development of Mocaf (Modified Cassava Flour) for Increasing Food and Economic Diversification Post Merapi Eruption. Inoteks 19 (1): 52 - 69. e-ISSN: 2620-6404.

Pangestu, G. A., Pujaningsih, R. I., Mangisah, I. (2018). Effect of Rations Containing Fermented Bean Sprouts on Digestion of Crude Fiber, Crude Protein, and Metabolic Energy in Local Starter Phase Ducks Integrated. Animal Husbandry Scientific Journal 6 (1): 77-82.

Paramita, I. A. M. I., Mulyani, S., \& Hartiati, A. (2015). The Effect of Maltodextrin Concentration and Drying Temperature on the Characteristics of Sinom Beverage Powder. Journal of AgroIndustry Engineering and Management 3 (2): 58 68. ISSN: 2503-488X.

Rajapaksha, K. D. S. C. N., Somendrika, M. A. D., Wickramasinghe, I. (2017). Nutritional and Toxicological Composition Analysis of Selected 
Cassava Processed Products. Potravinarstvo Slovak Journal of Food Sciences 11 (1): 35-42.

Riansyah, A., Supriadi, A., Nopianti, R. (2013). The Effect of Temperature and Drying Time Differences on the Characteristics of Siamese Sepchogaster (Trichogaster pectoralis) Using the Oven. Fishtech 2 (1): 53 - 68. DOI: https://doi.org/10.36706/fishtech.v2i1.1103.

Rohyani, I. S., Aryanti, E., \& Suripto. (2015). Potential Nutrient Value of Local Food Plants in Lombok Island as the Base for Strengthening National Food Security. Journal of Science of Technology and Environment 1 (1): 43 - 47.

Saepudin, L., Setiawan, Y., \& Sari, P. D. (2017). The Influence of Comparison of Substitution of Breadfruit Flour and Wheat Flour in Making Bread. Journal Agroscience 7 (1): 227 - 243. e-ISSN: 2579-7891.

Sakya, A. T. (2016). Increased Availability of Micro Nutrition in Plants: Efforts to Reduce Malnutrition in Humans. Caraka Tani - Journal of Sustainable Agriculture 31 (2): 118 - 128.

Salimna, Izzati, M., \& Haryanti, S. (2014). Proximate Analysis and Organoleptic Test of Artificial Rice Based on Cassava Flour (Manihot esculenta Crantz) and Red Bean Flour (Phaseolus vulgaris L.) with Comparison of Different Formulations. Journal of Biology 3 (1): 62 - 69.

Sarastuti, M. \& Yuwono, S. S. (2015). The Effect of Covenant and Warming on the Properties of Instant Cingur Rujak Seasoning During Storage.
Journal of Food and Agro-Industry 3 (2): 464 475.

Sarifudin, A., Ekafitri, R., Surahman, D. N., \& Putri, S. K. D. F. A. (2015). Effects of Egg Addition on Proximate Content, Characteristics of Free Water Activity (aw) and Texture of Banana-Based Snack Bars (Musa paradisiaca). Agritech Journal 35 (1): 1-8. DOI: https://doi.org/10.22146/agritech.9413.

Subekti, I., Khumaida, N., Ardie, S. W., Syukur, M. (2018). Evaluation of Ybi-ray mutant starch yield and content of gamma ray irradiation. J. Agron. Indonesia 46 (1): 64 - 70.

Sundari, D., Almasyhari, Lamin, A. (2015). Effect of Cooking Process on Nutrient Composition of Protein Source Foodstuffs. Litbangkes Media 25 (4): 235 - 242. DOI: 10.22435 / mpk.v25i4.4590.235242.

Tambunan, B. Y., Ginting, S., \& Lubis, L. M. (2017). Effect of Temperature and Drying Time on the Quality of Padang Sate Seasoning Powder. Journal of Food and Agricultural Engineering 5 (2): 258 - 266.

Wahyuni, R., Guswandi, Rivai, H. (2014). The Effect of Drying with Oven, Dry Wind, and Direct Sunlight on the Quality of Simultaneous Herb Sambiloto. Journal of Pharmacy Higea 6 (2): 126-132. e-ISSN: 2541-3554.

Yulifianti, R., Ginting, E., \& Utomo, J. S. (2012). Modified Kasava Flour as a Substitution of Wheat Material Supports Food Diversification. Palawija Bulletin (23): 1-12. 